\title{
STRUCTURE, OCCURRENCE AND BIOLOGICAL ACTIVITY OF ELLAGITANNINS: A GENERAL REVIEW*
}

\author{
Lidia Lipińska ${ }^{1}$, Elżbieta Klewicka ${ }^{1 凶}$, Michał Sójka $^{2}$ \\ ${ }^{1}$ Institute of Fermentation Technology and Microbiology, Lodz University of Technology \\ Wółczańska 171/173, 90-924 Łódź, Poland \\ Institute of Chemical Technology of Food, Lodz University of Technology \\ Stefanowskiego 4/10, 90-924 tódź, Poland
}

\begin{abstract}
The present paper deals with the structure, occurrence and biological activity of ellagitannins. Ellagitannins belong to the class of hydrolysable tannins, they are esters of hexahydroxydiphenoic acid and monosaccharide (most commonly glucose). Ellagitannins are slowly hydrolysed in the digestive tract, releasing the ellagic acid molecule. Their chemical structure determines physical and chemical properties and biological activity. Ellagitannins occur naturally in some fruits (pomegranate, strawberry, blackberry, raspberry), nuts (walnuts, almonds), and seeds. They form a diverse group of bioactive polyphenols with anti-inflammatory, anticancer, antioxidant and antimicrobial (antibacterial, antifungal and antiviral) activity. Furthermore, they improve the health of blood vessels. The paper discusses the metabolism and bioavailability of ellagitannins and ellagic acid. Ellagitannins are metabolized in the gastrointestinal tract by intestinal microbiota. They are stable in the stomach and undergo neither hydrolysis to free ellagic acid nor degradation. In turn, ellagic acid can be absorbed in the stomach. This paper shows the role of cancer cell lines in the studies of ellagitannins and ellagic acid metabolism. The biological activity of these compounds is broad and thus the focus is on their antimicrobial, anti-inflammatory and antitumor properties. Ellagitannins exhibit antimicrobial activity against fungi, viruses, and importantly, bacteria, including antibiotic-resistant strains such as methicillinresistant Staphylococcus aureus.
\end{abstract}

Key words: ellagitannins, hydrolysable tannins, biological activity

\section{INTRODUCTION}

In recent years, the interest in the biological activity of molecules occurring in unprocessed food has increased. Polyphenols, which include ellagitannins, constitute a significant part of such compounds. Ellagitannins are characterized by a complex chemical structure. They are subject to spontaneous lactonisation releasing hexahydroxydiphenoic acid (HHDP), which can be converted into ellagic acid. The mechanisms of the biological activity of ellagitannins vary. They exhibit antioxidant, antimicrobial, anti-inflammatory, and anticancer properties, as confirmed by numerous studies [Törrönen 2009]. Moreover, ellagitannins prevent obesity [Xiang et al. 2008]. Intake of food rich in ellagitannins can improve health and prevent chronic conditions such as cardiovascular diseases, neurodegenerative diseases, and cancer [Scalbert et al. 2005,

\footnotetext{
『elzbieta.klewicka@p.lodz.pl, phone: +48 426313271

*This study was supported by a grant of National Science Center (Grant No. 2013/09/B/NZ9/01806). 
Erdman et al. 2007]. The anticancer activity of ellagitannins and their metabolites is associated with their free radical trapping ability. Therefore, ellagitannins prevent or reduce oxidative stress, which could otherwise induce carcinogenesis, and which is a major cause of atherosclerosis and cardiovascular diseases [Kaneto et al. 2010].

Ellagitannins exhibit a wide range of biological activity, reflected in their anti-atherogenic [Kaplan et al. 2001, Khateeb et al. 2010], antithrombotic [Teng et al. 1997, Umar et al. 2003, Crescente et al. 2009, De Lange et al. 2007, Mattiello et al. 2009], anti-inflammatory [Lee et al. 2006, Na et al. 2006, Ngoumfo et al. 2008] and anti-angiogenic [Jeon et al. 2005, Lee and Lee 2005, Oak et al. 2006] properties. Studies have confirmed a correlation between the consumption of foods rich in ellagitannins (walnuts, pomegranates) and improved cardiovascular health [Beretta et al. 2009, Larossa et al. 2010].

Ellagitannins are classified as nutraceuticals due to their health-promoting properties and significant biological activity. Currently, there are a number of commercially available extracts of medicinal plants and food products containing ellagic acid or ellagitannins, for example: VitaPurity Ellagic Ultra ${ }^{\mathrm{TM}}$, Ellagic acid Young Again ${ }^{\circledR}$, PomActiv ${ }^{\mathrm{TM}}$, and Pomegranate Extract.

\section{THE CHEMICAL STRUCTURE AND METABOLISM OF ELLAGITANNINS}

Ellagitannins are esters of HHPD and monosaccharide, usually beta-D-glucose [Chemistry... 2009]. There may be monomeric (nupharin A, geraniin, tellimagrandin II), oligomeric (nupharin $\mathrm{E}$, nupharin $\mathrm{C}$, hirtellin A), or C-glycosidic (vescalagin, castalagin). Ellagitannins tend to form high molecular weight dimers and oligomers. The monomer units are carbon-oxygen-carbon bonded [Grundhöfer et al. 2001, Seeram et al. 2006, Silva Pinto et al. 2008]. Examples of monomeric and oligomeric ellagitannins are shown in Figure 1.

C-glycosidic ellagitannins are characterised by a highly specific intermolecular bond between the anomeric carbon of one monomer and HHDP or the galloyl group of another monomer [Chemistry... 2009]. The chemical structure of ellagitannins has an influence on their susceptibility to hydrolysis. Moreover, being compounds of complex structure, ellagitannins readily undergo chemical reactions (transformation, isomerization and oligomerization). This group of compounds has diverse physical properties.

The structural diversity of ellagitannins and their hydrolytic susceptibility lead to health benefits [Klimczak and Król 2010]. The ester linkages in ellagitannins hydrolyse relatively slowly, which causes prolonged gastrointestinal secretion of ellagic acid [Larrosa et<smiles>O=C(OCC1OC(OC(=O)c2cc(O)c(O)c(O)c2)C(OC(=O)c2cc(O)c(O)c(O)c2-c2c(O)c(O)c(O)c(O)c2C(=O)O)C(Oc2cc(O)c(O)c(O)c2O)C1OC(=O)c1cc(O)c(O)c(O)c1)c1cc(O)c(O)c(O)c1</smiles>

a

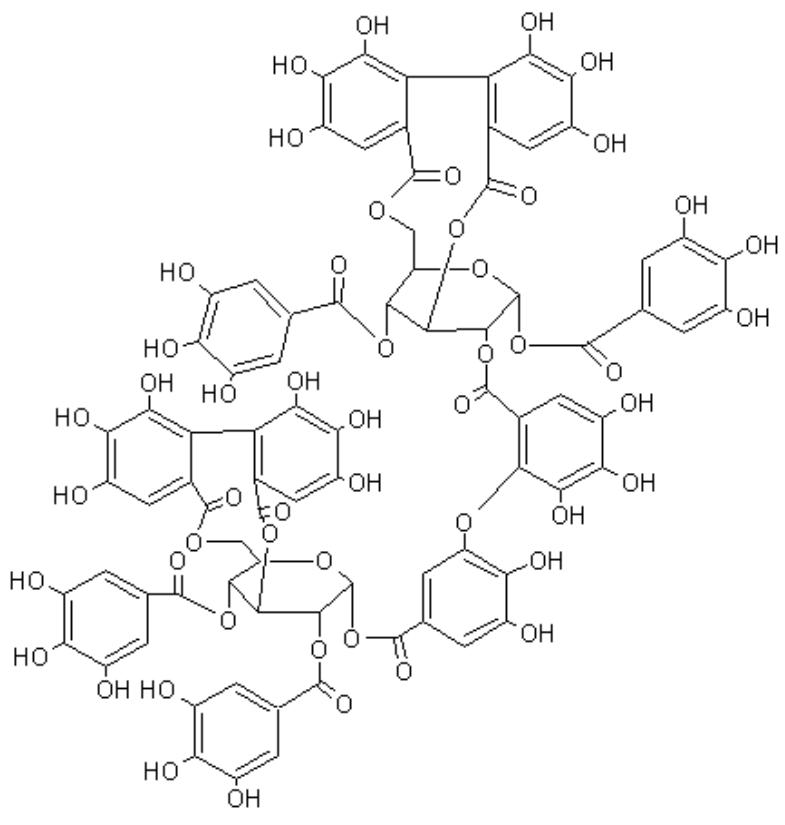
b

Fig. 1. Examples of (a) monomeric ellagitannin nupharin $A$ (molecular weight $939 \mathrm{~g} / \mathrm{mol}$ ), (b) oligomeric ellagitannin nupharin E (molecular weight $1875 \mathrm{~g} / \mathrm{mol}$ ) 
al. 2010]. Some raw materials other than ellagitannins may contain unrelated ellagic acid molecules. In the case of plants containing no free ellagic acid, all the ellagic acid particles present in the gastrointestinal tract are the product of ellagitannin hydrolysis. Ellagic acid may therefore be used as a chemical indicator of the presence of hydrolyzable tannins in plant foods and as a biomarker of dietary ellagitannin bioavailability [Seeram et al. 2004].

In the gastrointestinal tract free ellagic acid is converted to dimethylated ellagic acid glucuronide, which is then metabolized by the colon microbiota to hydroxy derivatives of dibenzopyran-6H-6-one, which include the following compounds: 3,8-dihydroxyglucuronide-6H-dibenzo- $\beta$-D-pyran-6-one, its aglycone urolithin A, glucuronide of hydroxy- $6 \mathrm{H}$-dibenzo$-\beta$-D-pyran-6-one, its aglycone urolithin $B$ and glucuronide of 3,8,10-trihydroxy-6H-dibenzo- $\beta$-D-pyran-6-one [Tomas-Barberan et al. 2009].

Figure 2 shows changes induced in ellagitannins and ellagic acid by the gastrointestinal microbiota [Espin et al. 2013].
Fig. 2. Metabolism of ellagitannins and ellagic acid occurring with the participation of the intestinal microbiota

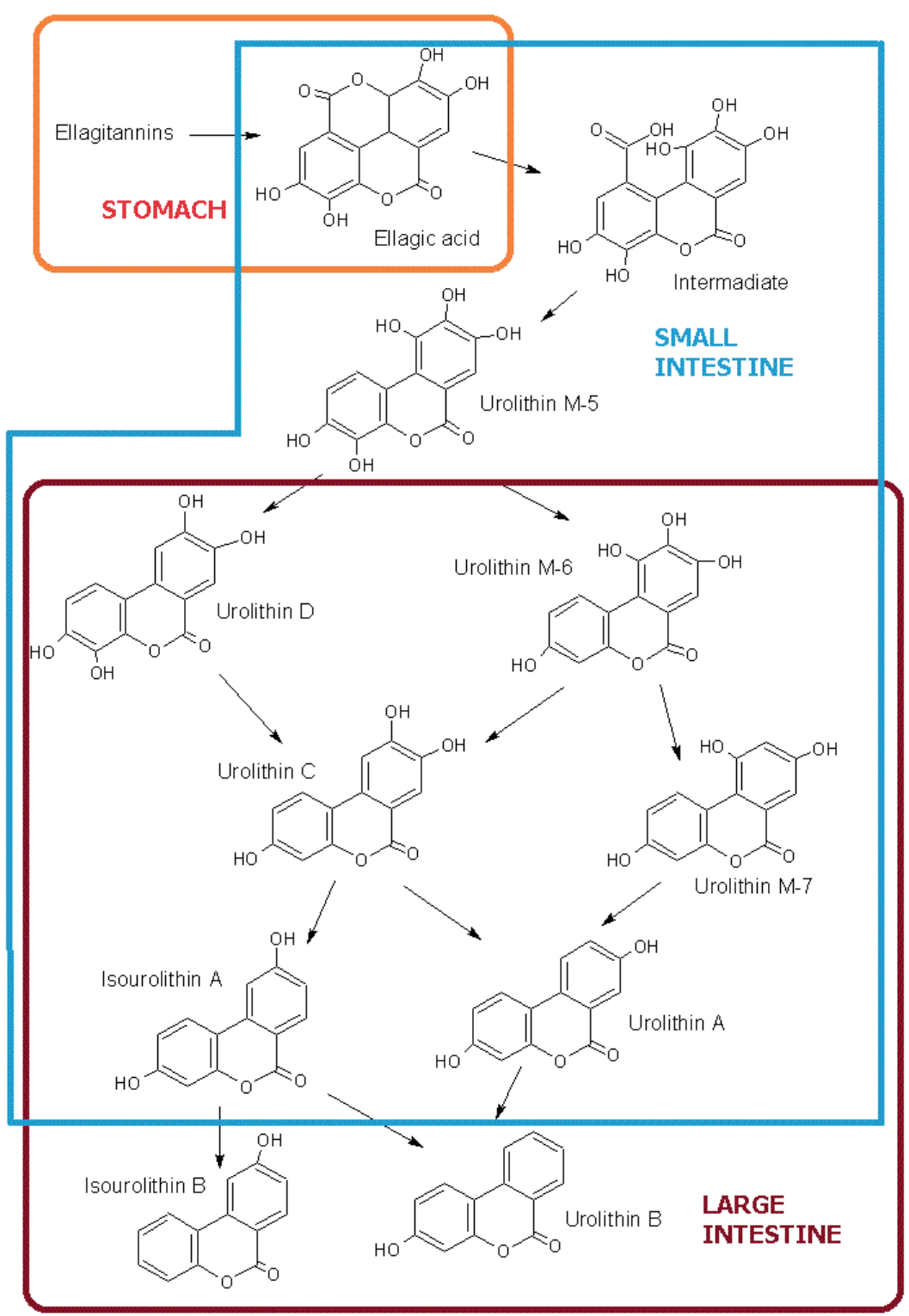


The most important products of ellagitannins are urolithins. They are formed by intestinal bacteria during the metabolism of non-absorbed nutrients containing ellagitannins. Urolithins are then incorporated into enterohepatic circulation [Cerdá et al. 2004, Tomas-Barberan et al. 2006]. Urolithins are bioactive compounds which can play the role of hormone analogs [Heber 2008, Seeram et al. 2004, 2006].

\section{THE OCCURRENCE OF ELLAGITANNINS IN PLANTS}

Ellagitannins occur naturally in certain fruits, herbs and seeds. They are abundant in some berries (especially raspberries, blackberries, currants, and strawberries), as well as walnuts, pistachios, cashews, chestnuts, acorns, and pecans [Hannu 2004, Zafrilla et al. 2001, Blomhoff et al. 2006, Villarreal-Lozoya et al.

Table 1. Ellagitannins and ellagic acid content in food products

\begin{tabular}{|c|c|c|c|}
\hline Food product & Ellagitannin & Content & Reference \\
\hline Raspberry & $\begin{array}{l}\text { Sanguiin H-6 } \\
\text { Lambertianin C }\end{array}$ & $\begin{array}{l}2.63-3.30 \mathrm{mg} \cdot \mathrm{g}^{-1} \\
0.51-3.30 \mathrm{mg} \cdot \mathrm{g}^{-1}\end{array}$ & $\begin{array}{l}\text { Koponen et al. } 2007 \\
\text { Törrönen } 2009\end{array}$ \\
\hline Cloudberry & $\begin{array}{l}\text { Sanguiin H-6 } \\
\text { Lambertianin C }\end{array}$ & $\begin{array}{l}3.15 \mathrm{mg} \cdot \mathrm{g}^{-1} \\
0.56-3.60 \mathrm{mg} \cdot \mathrm{g}^{-1}\end{array}$ & $\begin{array}{l}\text { Koponen et al. } 2007 \\
\text { Törrönen } 2009\end{array}$ \\
\hline Strawberry & $\begin{array}{l}\text { Agrimoniin } \\
\text { Sanguiin H-6 }\end{array}$ & $\begin{array}{l}0.77-0.85 \mathrm{mg} \cdot \mathrm{g}^{-1} \\
0.25 \mathrm{mg} \cdot \mathrm{g}^{-1}\end{array}$ & $\begin{array}{l}\text { Koponen et al. } 2007 \\
\text { Aaby et al. } 2007\end{array}$ \\
\hline Blackberry & $\begin{array}{l}\text { Sanguiin H-6 } \\
\text { Lambertianin C }\end{array}$ & $1.50-2.00 \mathrm{mg} \cdot \mathrm{g}^{-1}$ & $\begin{array}{l}\text { Clifford and Scalbert } 2000 \\
\text { Sangiovanni et al. } 2013\end{array}$ \\
\hline Arctic blackberry & $\begin{array}{l}\text { Potentillin } \\
\text { (synonym: } \\
\text { Casuarictin) }\end{array}$ & $0.69-3.20 \mathrm{mg} \cdot \mathrm{g}^{-1}$ & $\begin{array}{l}\text { Salminen et al. } 2001 \\
\text { Hukkanen et al. } 2008 \\
\text { Törrönen } 2009\end{array}$ \\
\hline Pomegranate & Punicalagin & $0.35-0.75 \mathrm{mg} \cdot \mathrm{g}^{-1}$ & Gil et al. 2000 \\
\hline Muscadine grapes & Sanguiin H-5 & $0.03-0.91 \mathrm{mg} \cdot \mathrm{g}^{-1}$ & Törrönen 2009 \\
\hline Walnut & Pedunculagin & $16.04 \mathrm{mg} \cdot \mathrm{g}^{-1}$ & Anderson et al. 2001 \\
\hline Pecan & Pedunculagin & $20.96-86.20 \mathrm{mg} \cdot \mathrm{g}^{-1}$ & Malik et al. 2009 \\
\hline Chestnut & Castalagin & $0.16-2.49 \mathrm{mg} / 100 \mathrm{~g}$ & Goncalves et al. 2010 \\
\hline Pomegranate juice & Punicalagin & $\begin{array}{l}1500-1900 \mathrm{mg} \cdot \mathrm{L}^{-1} \\
2020-2660 \mathrm{mg} \cdot \mathrm{L}^{-1}\end{array}$ & $\begin{array}{l}\text { Gil et al. } 2010 \\
\text { Cerdá et al. } 2006\end{array}$ \\
\hline Muscadine grape juice & Sanguiin H-5 & $8-84 \mathrm{mg} \cdot \mathrm{L}^{-1}$ & Lee and Talcott 2002 \\
\hline Raspberry jam & $\begin{array}{l}\text { Sanguiin H-6, } \\
\text { Lambertianin C }\end{array}$ & $0.76 \mathrm{mg} \cdot \mathrm{g}^{-1}$ & Koponen et al. 2007 \\
\hline Strawberry jam & $\begin{array}{l}\text { Agrimoniin, } \\
\text { Sanguiin H-6 }\end{array}$ & $0.24 \mathrm{mg} \cdot \mathrm{g}^{-1}$ & Koponen et al. 2007 \\
\hline $\begin{array}{l}\text { Red wine aging } \\
\text { in oak barrels }\end{array}$ & Vescalagin & $\begin{array}{l}9.4 \mathrm{mg} \cdot \mathrm{L}^{-1} \\
50.0 \mathrm{mg} \cdot \mathrm{L}^{-1}\end{array}$ & $\begin{array}{l}\text { Glabasnia and Hofmann } 2006 \\
\text { Clifford and Scalbert } 2000\end{array}$ \\
\hline Muscadine grape wine & Sanguiin H-5 & $2-65 \mathrm{mg} \cdot \mathrm{L}^{-1}$ & Lee and Talcott 2002 \\
\hline Whiskey & Vescalagin & $1-2 \mathrm{mg} \cdot \mathrm{L}^{-1}$ & Glabasnia and Hofmann 2006 \\
\hline Cognac & Vescalagin & $31-55 \mathrm{mg} \cdot \mathrm{L}^{-1}$ & Clifford and Scalbert 2000 \\
\hline
\end{tabular}


2007]. Pomegranates and grapes are exceptionally rich in ellagitannins [Lee and Talcott 2002]. In addition, ellagitannins may be present in alcohol - which was aged in wooden barrels. This is associated with the migration of ellagitannins from wood to the alcohol. Free ellagic acid is also found in some honeys. The occurrence of ellagitannins and ellagic acid in natural and processed plant products is shown in Table 1.

Some plants rich in ellagitannins are commonly used for medical purposes, especially in Asia [Okuda et al. 2009]. This group of medicinal plants includes the following species: agrimony (Agrimonia pilosa, containing agrimoniin), camellia (Camellia japonica, camelitannin A), dogwood (Cornus officinalis, cornussin A), geranium (Geranium thunbergii, geraniin), avens (Geum japonicum, gemin A), amber tree (Liquidambar formosana, casuarictin), mallotus (Mallotus japonicus, mallotusinic acid), Oenothera (Oenothera erythrosepala, oenothein B), pomegranate (Punica granatum, granatin $\mathrm{B})$, rose (Rosa rugosa, rugosin) and Terminalia chebula (chebulinic acid).

\section{THE BIOAVAILABILITY OF ELLAGITANNINS AND ELLAGIC ACID}

The bioavailability of ellagitannins and free ellagic acid depends on the part of gastrointestinal tract in which these compounds are absorbed. In vitro studies have shown that ellagitannins are stable under the conditions of the acidic gastric environment $(\mathrm{HCl}, \mathrm{pH}$ 1.8-2.0) and in the presence of gastric enzymes (pepsin, rennin, gastric lipase) and undergo neither hydrolysis to free ellagic acid nor degradation [Haslam 2009]. Furthermore, by pancreatic enzymes and bile salts do not hydrolyse ellagitannins into ellagic acid, either. Acidified chyme is transported in small portions from the stomach to further sections of the gastrointestinal tract (the duodenum and small intestine), where $\mathrm{pH}$ is higher and more suitable for hydrolysis of ellagitannins ( $\mathrm{pH}$ 7.1-8.4). The best conditions for hydrolysis are at neutral or slightly alkaline $\mathrm{pH}$ in the range from 7.0 to 7.3 [Larrosa et al. 2006]. In the stomach, the absorption of ellagitannins is not possible due to their complex chemical structure. However, the stomach is the first part of the digestive system where free ellagic acid molecules can be absorbed.
Epithelial cell lines have been successfully used in transepithelial transport studies. They allow for comparison of the bioavailability of a large number of compounds under the same conditions [Grajek 2007]. Metabolism studies using the gastric KATO-III cell line and the intestinal Caco-2 cell line have shown that the absorption and metabolism of ellagitannins and ellagic acid are associated with specific products of cell metabolism. Therefore, the uptake and hydrolysis of ellagitannins are not directly related to the type of cells but to the environmental conditions associated with the secretion of specific metabolites by the cells [Tomas-Barberan et al. 2009]. Moreover, the greatest impact on the bioavailability of ellagitannins and ellagic acid is exerted by the effectiveness of their release from the food matrix, concentration, and the way of connecting with other ingredients in the medium [Grajek 2007]. Gastrointestinal cell lines in in vivo studies constitute a model of interaction between intestinal cells and ellagitannin extracts.

Ellagitannins are not absorbed by Caco- 2 cells, but their concentration in the culture medium decreases. This may be due to precipitation, degradation, or binding to the proteins present in the environment. In contract, ellagic acid is absorbed by gastrointestinal tract cells and can be quickly transformed into methyl ethers by catechol-O-methyltransferase (COMT, EC 2.1.1.6). COMT is an intracellular enzyme responsible for the degradation of catecholamines by introducing one or two methyl ethers into them.

Research into the absorption of ellagic acid by the cell line Caco-2 confirmed significant accumulation of ellagic acid in the cells. As much as $93 \%$ of absorbed ellagic acid was permanently bound to macromolecules such as proteins and DNA. The accumulation of ellagic acid in intestinal epithelial cells is proportional to the incubation time in a medium containing ellagic acid [Whitley et al. 2003].

Cancer cell lines are used to assess the impact of external and internal factors on cells, but they are not always ideal models for such interactions, for example, in the case of apoptosis. It would be preferable to find an agent that would trigger apoptosis of tumor cells. In vitro studies using punicalagin and Caco-2 cells have shown that punicalagin and ellagic acid induce apoptosis in Caco-2 cancer cells, but not in normal cells. Furthermore, punicalagin undergoes hydrolysis 
in Caco-2 cells to dimethyl derivatives of ellagic acid, which require the active presence of COMT, but not to ellagic acid in contrast to normal cells [Larrosa et al. 2006].

During the remaining phases of digestion, ellagitannins and ellagic acid are transformed by the intestinal microbiota to dibenzopyranone metabolites - urolithin $\mathrm{A}$ and $\mathrm{B}$, which are absorbed in the intestine and undergo glucuronidation. In this case, methyl ether is not formed and urolithins do not have ortho-dihydroxyphenyl units in their structure. Besides, urolithin A (3,8-dihydroxy-6H-dibenzo-[b,d]pyran-6-one) undergoes hydroxylation by cytochrome P-450, therefore, it may have an improved ability to glucuronidate and enhance the excretion of specific metabolites [Tomas-Barberan et al. 2009].

\section{THE ANTIMICROBIAL ACTIVITY OF ELLAGITANNINS}

Ellagitannins exhibit antimicrobial activity against bacteria, fungi and even viruses. Antibacterial activity is the main type of their interactions [Funatogawa et al. 2004, Taguri et al. 2006]. The effect of the presence of ellagitannins in bacteria has been examined and it has been found that the hydrolysable tannins have an antibacterial effect for a short time (up to seven days), regardless of their molecular weight [Yoshida et al. 2009, Kołodziej et al. 2000]. The antibacterial activity of ellagitannins, such as corilagin or phyllanthusiin $C$, against Escherichia coli, Klebsiella pneumoniae, Bacillus subtilis, Pseudomonas aeruginosa, and Proteus mirabilis is low (MIC $1000-2000 \mu \mathrm{g} \cdot \mathrm{mL}^{-1}$ ) [Yoshida et al. 2009]. Corilagin showed a moderate influence on Staphylococcus aureus (MIC $250 \mathrm{mg} \cdot \mathrm{mL}^{-1}$ ) as compared to the well-studied effect of penicillin G (MIC $125 \mathrm{mg} \cdot \mathrm{mL}^{-1}$ against Staphylococcus) [Hatano et al. 2005, 2008, Shiota et al. 2004, Yoshida et al. 2009]. The inhibition of the growth of fungi, such as Candida albicans and Cryptococcus neoformans, by corilagin and phyllanthusiin $\mathrm{C}$ is similar to their effect against Staphylococcus spp. (MIC 125-500 $\mathrm{mg} \cdot \mathrm{mL}^{-1}$ ) [Yoshida et al. 2009, Kołodziej et al. 2000].

Another advantage of ellagitannins is their inhibitory activity against antibiotic-resistant bacteria, such as methicillin-resistant Staphylococcus aureus (MRSA) or bacteria resistant to $\beta$-lactam antibiotics
[Yoshida et al. 2009]. Polyphenols derived from blackberry roots exhibit bactericidal activity against MRSA, carbapenem-resistant Acinetobacter baumannii and Staphylococcus anthracis. Moreover, polyphenols extracted from blackberry fruits show stronger antimicrobial properties than those extracted from the roots [Kim et al. 2013].

The antifungal properties of ellagitannins have not been investigated sufficiently. Studies have shown the inhibitory activity of ellagitannins isolated from the plant Euphorbia antisyphilitica Zucc against the phytopathogenic fungi: Alternaria alternata, Fusarium oxysporum f. sp. lycopersici, Colletotrichum gloeosporioides and Rhizoctonia solani. In vitro analysis has confirmed the antifungal activity of candelitannin, an ellagitannin isolated from Euphorbia, against all the tested fungi (Fig. 3 a) [Ascacio-Valdés et al. 2013].

Similar effects have been observed by scientists studying the antagonistic activity of ellagitannins isolated from the plant Ocotea odorifera (Lauraceae) [Yamaguchi et al. 2011]. The ellagitannin known as tellimagrandin II (Fig. 3 b) has been found to inhibit the yeast Candida parapsilosis ATCC 22019. The minimum inhibitory concentration of tellimagrandin II is $12.5 \mu \mathrm{g} \cdot \mathrm{mL}^{-1}$ [Yamaguchi et al. 2011].

According to Grywalska et al. [2013], ellagitannins and ellagic acid inhibit the growth of EpsteinBarr virus (EBV). This virus attacks the $T$ antigen and may have oncogenic activity being a factor causing endemic lymphoma (Burkitt's lymphoma) or cancer of the oropharynx.

\section{ANTI-INFLAMMATORY ACTIVITY}

The anti-inflammatory activity of ellagitannins and ellagic acid has been tested on animals (mice) infected with pneumonia [Rogerio 2013]. Pneumonia is characterised by high morbidity and mortality [Matthay et al. 2012]. Ellagic acid has been found to mitigate inflammation and reduce the duration of the disease. In addition, it reduces the level of proinflammatory cytokines IL-6 and increases that of anti-inflammatory cytokines IL-10 [Rogerio 2013].

The anti-inflammatory activity of polyphenols isolated from blackberries (Rubus coreanus Mediquel) has been confirmed by analysing the levels of nitric oxide (NO), cytokines (IL-10020, IL-6 and IL-10) 


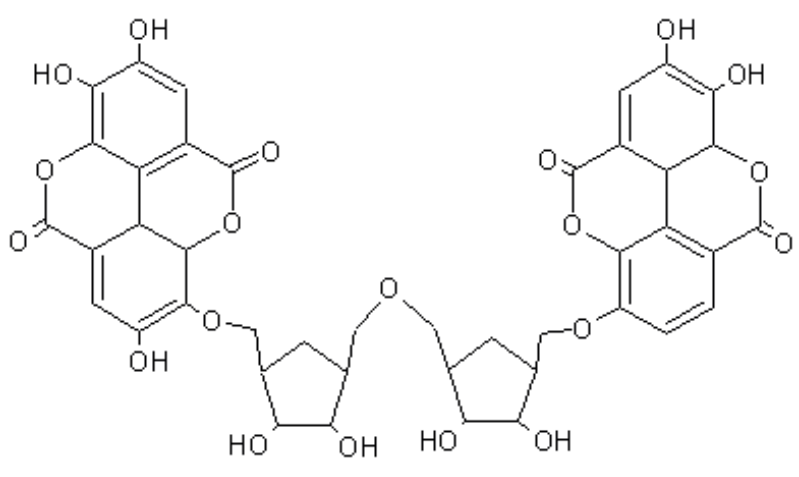

a

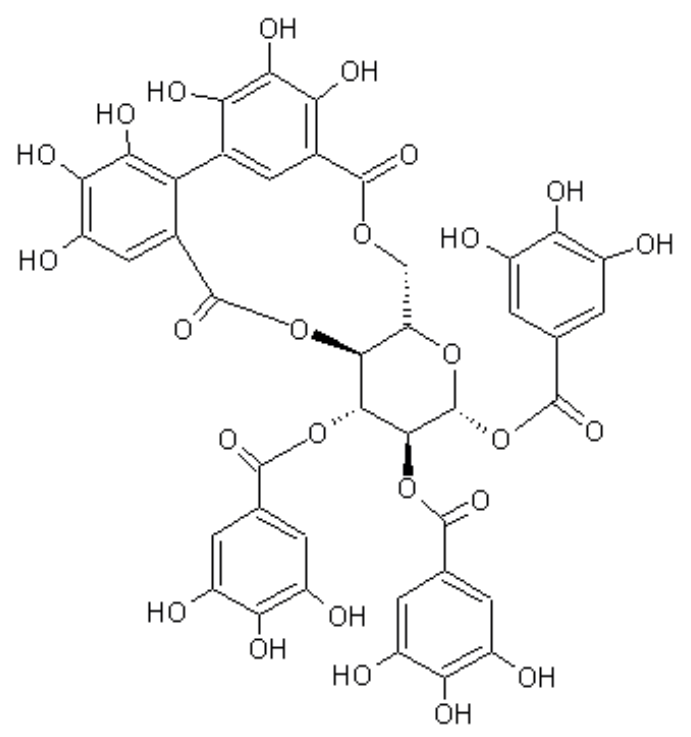

b

Fig. 3. Antifungal ellagitannins: a - candelitannin (molecular weight $863 \mathrm{~g} / \mathrm{mol}$ ), b - tellimagrandin II (molecular weight $939 \mathrm{~g} / \mathrm{mol}$ ) [Yamaguchi et al. 2011, Ascacio-Valdes et al. 2013]

and prostaglandin $\mathrm{E} 2\left(\mathrm{PGE}_{2}\right)$ produced in lipopolysaccharide-stimulated murine macrophages (RAW 264.7 cells). Furthermore, the polyphenols obtained from the roots exhibit a better anti-inflammatory effect than those derived from the fruits [Kim et al. 2013].

\section{ANTITUMOR ACTIVITY OF ELLAGITANNINS}

The antitumor activity of ellagitannins has been determined as an example of their selective cytotoxic properties against cancer cell lines [Okuda et al. 2009].
A study using an animal model (rats) confirmed the anticancer properties of the ellagic acid contained in some berries against esophageal cancer [Carlton et al. 2001, Kresty et al. 2001, Stoner et al. 1999]. In addition, it has been shown that ellagic acid inhibits some carcinogenic compounds such as polycyclic aromatic hydrocarbons, nitrosamines and heterocyclic aromatic amines. Ellagitannins which may inhibit some mutagenic properties include geraniin, mallotusinic acid, pedunculagin, agrimoniin, and epigallocatechin gallate (EGCG). The main examples of inhibited substances are: Trp-P-1 (3-amino-1,4-dimethyl-5H pyrido[4,3-b]indole), MNNG (N-methyl-N'-nitro-N-nitrosoguanidine) and N-OH-Trp-P-2 (3-hydroxyamino-1-methyl-5H-pyrido[4,3-b]indole) [Okuda et al. 2009].

Ellagitannins limit the mutagenic properties of some chemical compounds and can hamper the initiation of carcinogenesis. Plants rich in ellagitannins may prevent or delay the lengthy carcinogenesis process [Okuda et al. 2009]. Ellagitannins and ellagic acid inhibit cancers of the mouth, esophagus, lung, breast, liver and colon [Aqil et al. 2012, González-Sarrías et al. 2013 a, b, Sakagami et al. 2000, Wang et al. 2010, 2013].

Antitumor tests have been conducted using mice whose skin surface was treated with ellagic acid and ellagitannins isolated from the plants Cowania mexicana and Coleogyne ramosissima. Then, the mice were exposed to two chemical compounds: 12-O-tetradecanoylforbol-13-acetate (TPA) and 7,12-dimethylbenzanthracene (DMBA). TPA and DMBA can initiate carcinogenesis acting together. Research has shown that the level of TPA was significantly reduced due to ellagitannins prior to its reaction with the other agent, DMBA [Okuda et al. 2009].

\section{SUMMARY}

The present paper reports on a number of studies concerning the bioavailability and biological activity of ellagitannins. The existing research is insufficient, especially in the field of anti-tumor and antifungal activity of ellagitannins. Furthermore, since molds and yeasts are the most common cause of food spoilage, if ellagitannins are confirmed to exhibit some antifungal activity against selected strains, they could be 
used as alternative food preservatives. Another area of research where current knowledge is limited is the anti-cancer activity of ellagitannins. Scientific reports show a correlation between consumption of food rich in ellagitannins and the inhibition of tumorigenesis, but the mechanism of this process is not yet understood. Currently, oxidative stress is the most likely factor linked with the development of cancer. Given the above, further studies on the biological activity of ellagitannins are required.

\section{REFERENCES}

Aaby K., Wrolstad R.E., Ekeberg D., Skrede G., 2007. Polyphenol composition and antioxidant activity in strawberry purees, impact of achen e level and storage. J. Agric. Food Chem. 55, 13, 5156-5166.

Aqil F., Gupta A., Munagala R., Jeyabalan J., Kausar H., Sharma R.J., Gupta R.C., 2012. Antioxidant and antiproliferative activities of anthocyanin/ellagitannin-enriched extracts from Syzygium cumini L. (Jamun, the Indian Blackberry). Nutr. Cancer 64, 428-438.

Anderson K.J., Teuber S.S., Gobeille A., Cremin P., Waterhouse A.L., Steinberg F.M., 2001. Walnut polyphenolics inhibit in vitro human plasma and LDL oxidation. J. Nutr. 131, 11, 2837-2842.

Ascacio-Valdés J., Burboa E., Aguilera-Carbo A.F., Aparicio M., Pérez-Schmidt R., Rodríguez R., Aguilar C.N., 2013. Antifungal ellagitannin isolated from Euphorbia antisyphilitica Zucc. Asian Pac. J. Trop. Biomed. 3, 1, 41-46.

Beretta G., Rossoni G., Santagati N.A., Facino R.M., 2009. Anti-ischemic activity and endothelium-dependent vasorelaxant effect of hydrolysable tannins from the leaves of Rhus coriaria (Sumac) in isolated rabbit heart and thoracic aorta. Planta Med. 5, 14, 1482-1488.

Blomhoff R., Carlsen M.H., Andersen L.F., Jacobs D.R., 2006. Health benefits of nuts: potential role of antioxidants. Br. J. Nutr. 96, 1, 52-60.

Carlton P.S., Kresty L.A., Siglin J.C., Morse M.A., Lu J., Morgan C., Stoner G.D., 2001. Inhibition of N-nitrosomethylbenzylamine-induced tumorigenesis in the rat esophagus by dietary freeze-dried strawberries. Carcinogenesis 22, 3, 441-446.

Cerdá B., Espin J.C., Parra S., Martínez P., Tomás-Barberán F.A., 2004. The potent in vitro antioxidant ellagitannins from pomegranate juice are metabolised into bioavailable but poor antioxidant hydroxy-6H-dibenzopyran-6-one derivatives by the colonic microflora of healthy humans. Eur. J. Nutr. 43, 4, 205-220.

Cerdá B., Soto C., Albaladejo M.D., Martinez P., Sanchez-Gasco F., Tomás-Barberán F., Espin J.C., 2006. Pomegranate juice supplementation in chronic obstructive pulmonary disease: a 5-week randomized, doubleblind, placebo-controlled trial. Eur. J. Clin. Nutr. 60, 2, 245-253.

Chemistry and biology of ellagitannins: an underestimated class of bioactive plant polyphenols. 2009. Ed. S. Quideau. World Scientific Singapore.

Clifford M.N., Scalbert A., 2000. Ellagitannins - nature, occurrence and dietary burden. J. Sci. Food Agric. 80, 7, $1118-1125$.

Crescente M., Jessen G., Momi S., Höltje H.D., Gresele P., Cerletti C., de Gaetano G., 2009. Interactions of gallic acid, resveratrol, quercetin and aspirin at the platelet cyclooxygenase-1 level. Functional and modelling studies. J. Thromb. Haemost. 102, 2, 336-346.

De Lange D.W., Verhoef S., Gorter G., Kraaijenhagen R.J., Van De Wiel A., Akkerman J.W.N., 2007. Polyphenolic grape extract inhibits platelet activation through PECAM-1: An explanation for the French paradox. Alcoholism: Clin. Exp. Res. 31, 8, 1308-1314.

Erdman J.W., Balentine D., Arab L., Beecher G., Dwyer J.T., Folts J., Burrowes J., 2007. Flavonoids and heart health: Proceedings of the ILSI North America flavonoids workshop. May 31-June 1, 2005. Washington D.C. J. Nutr. 137, 3, 718-737.

Espin J.C., Larrosa M., García-Conesa M.T., Tomás-Barberán F., 2013. Biological significance of urolithins, the gut microbial ellagic acid-derived metabolites: The evidence so far. Evid.-Based Compl. Alternat. Med. 2013, ID 270418

Funatogawa K., Hayashi S., Shimomura H., Yoshida T., Hatano T., Ito H., Hirai Y., 2004. Antibacterial activity of hydrolyzable tannins derived from medicinal plants against Helicobacter pylori. Microbiol. Immunol. 48, 4, 251-261.

Gil M.I., Tomás-Barberán F.A., Hess-Pierce B., Holcroft D.M., Kader A.A., 2000. Antioxidant activity of pomegranate juice and its relationship with phenolic composition and processing. J. Agric. Food Chem. 48, 10, 4581-4589.

Glabasnia A., Hofmann T., 2006. Sensory-directed identification of taste-active ellagitannins in American (Quercus alba L.) and European oak wood (Quercus robur L.) and quantitative analysis in bourbon whiskey and oak-matured red wines. J. Agric. Food Chem. 54, 9, 3380-3390. 
Goncalves B., Borges O., Costa H.S., Bennett R., Santos M., Silva A.P., 2010. Metabolite composition of chestnut (Castanea sativa Mill.) upon cooking: Proximate analysis, fibre, organic acids and phenolics. Food Chem. $122,1,154-160$.

González-Sarrías A., Giménez-Bastida J.A., Núñez-Sánchez M.Á., Larrosa M., García-Conesa M.T., Tomás-Barberán F.A., Espín J.C., 2013 a. Phase-II metabolism limits the antiproliferative activity of urolithins in human colon cancer cells. Eur. J. Nutr. 29, 1-12.

González-Sarrías A., Miguel V., Merino G., Lucas R., Morales J.C., Tomás-Barberán F., Espín J.C., 2013 b. The gut microbiota ellagic acid-derived metabolite Urolithin A and its sulfate conjugate are substrates for the drug efflux transporter breast cancer resistance protein (ABCG2/BCRP). J. Agric. Food Chem. 61, 18, 4352-4359.

Grajek W., 2007. Przeciwutleniacze w żywności. Aspekty zdrowotne, technologiczne, molekularne i analityczne [Antioxidants in food. Health, technology, molecular and analytical aspects]. WN-T Warszawa.

Grundhöfer P., Niemetz R., Schilling G., Gross G.G., 2001. Biosynthesis and subcellular distribution of hydrolyzable tannins. Phytochemistry 57, 6, 915-927.

Grywalska E., Markowicz J., Grabarczyk P., Pasiarski M., Roliński J., 2013. Epstein-Barr virus-associated lymphoproliferative disorders. Post. Hig. Med. Dośw. 67, 481-490.

Hannum S.M., 2004. Potential impact of strawberries on human health: a review of the science. Crit. Rev. Food Sci. Nutr. 44, 1, 1-17.

Haslam E., 2009. Preface. In: Chemistry and biology of ellagitannins: an underestimated class of bioactive plant polyphenols. Ed. S. Quideau. World Scientific Singapore.

Hatano T., Kusuda M., Inada K., Ogawa T.O., Shiota S., Tsuchiya T., Yoshida T., 2005. Effects of tannins and related polyphenols on methicillin-resistant Staphylococcus aureus. Phytochemistry 66, 17, 2047-2055.

Hatano T., Tsugawa M., Kusuda M., Taniguchi S., Yoshida T., Shiota S., Tsuchiya T., 2008. Enhancement of antibacterial effects of epigallocatechin gallate, using ascorbic acid. Phytochemistry 69, 18, 3111-3116.

Heber D., 2008. Multitargeted therapy of cancer by ellagitannins. Cancer Lett. 269, 2, 262-268.

Hukkanen A., Kostamo K., Kärenlampi S., Kokko H., 2008. Impact of agrochemicals on Peronospora sparsa and phenolic profiles in three Rubus arcticus cultivars. J. Agric. Food Chem. 56, 3, 1008-1016.

Jeon K.S., Na H.J., Kim Y.M., Kwon H.J., 2005. Antiangiogenic activity of 4-O-methylgallic acid from Canavalia gladiata, a dietary legume. Biochem. Biophys. Res. Commun. 330, 4, 1268-1274.

Kaneto H., Katakami N., Matsuhisa M., Matsuoka T.A., 2010. Role of reactive oxygen species in the progression of type 2 diabetes and atherosclerosis. Mediators Inflamm. 2010, DOI 10.1155/2010/453892.

Kaplan M., Hayek T., Raz A., Coleman R., Dornfeld L., Vaya J., Aviram M., 2001. Pomegranate juice supplementation to atherosclerotic mice reduces macrophage lipid peroxidation, cellular cholesterol accumulation and development of atherosclerosis. J. Nutr. 131, 8, 2082-2089.

Khateeb J., Gantman A., Kreitenberg A.J., Aviram M., Fuhrman B., 2010. Paraoxonase 1 (PON1) expression in hepatocytes is upregulated by pomegranate polyphenols: a role for PPAR- $\gamma$ pathway. Atherosclerosis 208, $1,119-125$

Kim S.K., Kim H., Kim S.A., Park H.K., Kim W., 2013. Anti-inflammatory and anti-superbacterial activity of polyphenols isolated from black raspberry. Korean J. Phys. Pharm. 17, 1, 73-79.

Klimczak E., Król B., 2010. Oznaczanie zawartości różnych form kwasu elagowego w ubocznych produktach przerobu truskawek [Macro- and microelements in determination of different forms of ellagic acid in by-products from strawberry processing]. Żywn. Nauka Techn. Jakość 17, 4, 81-94 [in Polish].

Kołodziej H., Kayser O., Latté K.P., Kiderlen A.F., 2000. Enhancement of antimicrobial activity of tannins and related compounds by immune modulatory effects. Plant Polyphen. 2, 575-594.

Koponen J.M., Happonen A.M. Mattila P.H., Törrönen A.R., 2007. Contents of anthocyanins and ellagitannins in selected foods consumed in Finland. J. Agric. Food Chem. 55, 4, 1612-1619.

Kresty L.A., Morse M.A., Morgan C., Carlton P.S., Lu J., Gupta A., Stoner G.D., 2001. Chemoprevention of esophageal tumorigenesis by dietary administration of lyophilized black raspberries. Cancer Res. 61, 16, 6112-6119.

Larrosa M., Tomás-Barberán F.A., Espín J.C., 2006. The dietary hydrolysable tannin punicalagin releases ellagic acid that induces apoptosis in human colon adenocarcinoma Caco-2 cells by using the mitochondrial pathway. J. Nutr. Biochem. 17, 9, 611-625.

Larrosa M., García-Conesa M.T., Espín J.C., Tomás-Barberán F.A., 2010. Ellagitannins, ellagic acid and vascular health. Mol. Aspects Med. 31, 6, 513-539.

Lee J.H., Talcott S.T., 2002. Ellagic acid and ellagitannins affect on sedimentation in muscadine juice and wine. J. Agric. Food Chem. 50, 14, 3971-3976. 
Lee S.J., Lee H.K., 2005. Sanguiin H-6 blocks endothelial cell growth through inhibition of VEGF binding to VEGF receptor. Arch. Pharm. Res. 28, 11, 1270-1274.

Lee G., Na H.J., Namkoong S., Jeong Kwon H., Han S., Ha K.S., Kim Y.M., 2006. 4-O-methylgallic acid downregulates endothelial adhesion molecule expression by inhibiting NF-кB-DNA-binding activity. Eur. J. Pharmacol. 551, 1, 143-151.

Malik N.S., Perez J.L., Lombardini L., Cornacchia R., Cisneros-Zevallos L., Braford J., 2009. Phenolic compounds and fatty acid composition of organic and conventional grown pecan kernels. J. Sci. Food Agric. 89, 13, 2207-2213.

Matthay M.A., Ware L.B., Zimmerman G.A., 2012. The acute respiratory distress syndrome. J. Clin. Invest. 122, 8, 2731-2740.

Mattiello T., Trifirò E., Jotti G.S., Pulcinelli F.M., 2009. Effects of pomegranate juice and extract polyphenols on platelet function. J. Med. Food 12, 2, 334-339.

Na H.J., Lee G., Oh H.Y., Jeon K.S., Kwon H.J., Ha K.S., Kim Y.M., 2006. 4-O-Methylgallic acid suppresses inflammation-associated gene expression by inhibition of redox-based NF- $\mathrm{BB}$ activation. Int. Immunopharm. 6, 10, 1597-1608.

Ngoumfo R.M., Ngounou G.E., Tchamadeu C.V., Qadir M.I., Mbazoa C.D., Begum A., Choudhary M.I., 2008. Inhibitory effect of macabarterin, a polyoxygenated ellagitannin from Macaranga barteri, on human neutrophil respiratory burst activity. J. Nat. Prod. 71, 11, 1906-1910.

Oak M.H., Bedoui J.E., Madeira S.F., Chalupsky K., Schini-Kerth V.B., 2006. Delphinidin and cyanidin inhibit PDGFAB-induced VEGF release in vascular smooth muscle cells by preventing activation of $\mathrm{p} 38$ MAPK and JNK. Br. J. Pharmacol. 149, 3, 283-290.

Okuda T., Yoshida T., Hatano T., Ito H., 2009. Ellagitannins renewed the concept of tannins. Chemistry and biology of ellagitannins. In: Chemistry and biology of ellagitannins: an underestimated class of bioactive plant polyphenols. Ed. S. Quideau. World Scientific Singapore, 1-54.

Rogerio P.A., 2013. Anti-inflammatory effects of ellagic acid on acute lung injury induced by acid in mice. Mediators Inflamm. 2013. DOI 10.1155/2013/164202.

Sakagami H., Jiang Y., Kusama K., Atsumi T., Ueha T., Toguchi M., Yoshida T., 2000. Cytotoxic activity of hydrolyzable tannins against human oral tumor cell lines - a possible mechanism. Phytomedicine 7, 1, 39-47.

Salminen J. P., Ossipov V., Haukioja E., Pihlaja K., 2001. Seasonal variation in the content of hydrolysable tannins in leaves of Betula pubescens. Phytochemistry 57, $1,15-22$.
Sangiovanni E., Vrhovsek U., Rossoni G., Colombo E., Brunelli C., Brembati L., Dell'Agli M., 2013. Ellagitannins from Rubus berries for the control of gastric inflammation: in vitro and in vivo studies. PloS ONE 8, 8, e71762.

Scalbert A., Manach C., Morand C., Rémésy C., Jiménez L., 2005. Dietary polyphenols and the prevention of diseases. Crit. Rev. Food Sci. Nutr. 45, 4, 287-306.

Seeram N.P., Lee R., Heber D., 2004. Bioavailability of ellagic acid in human plasma after consumption of ellagitannins from pomegranate (Punica granatum L.) juice. Clin. Chim. Acta 348, 1, 63-68.

Seeram N.P., Lee R., Scheuller H.S., Heber D., 2006. Identification of phenolic compounds in strawberries by liquid chromatography electrospray ionization mass spectroscopy. Food Chem. 97, 1, 1-11.

Shiota S., Shimizu M., Sugiyama J.I., Morita Y., Mizushima T., Tsuchiya T., 2004. Mechanisms of action of corilagin and tellimagrandin I that remarkably potentiate the activity of beta-lactams against methicillin-resistant Staphylococcus aureus. Microbiol. Immunol. 48, 1, 67.

Silva Pinto M., Lajolo F.M., Genovese M.I., 2008. Bioactive compounds and quantification of total ellagic acid in strawberries (Fragaria $\times$ ananassa Duch.). Food Chem. 107, 4, 1629-1635.

Stoner G.D., Kresty L.A., Carlton P.S., Siglin J.C., Morse M.A., 1999. Isothiocyanates and freeze-dried strawberries as inhibitors of esophageal cancer. Toxicol. Sci. 52, 95-100.

Taguri T., Tanaka T., Kouno I., 2006. Antibacterial spectrum of plant polyphenols and extracts depending upon hydroxyphenyl structure. Biol. Pharm. Bull. 29, 11, 2226-2235.

Teng C.M., Kang Y.F., Chang Y.L., Ko F.N., Yang S.C., Hsu F.L., 1997. ADP-mimicking platelet aggregation caused by rugosin E, an ellagitannin isolated from Rosa rugosa Thunb. Thromb. Haemost. 77, 3, 555-561.

Tomas-Barberan F.A., Espín J.C., García-Conesa M.T., 2009. Bioavailability and metabolism of ellagic acid and ellagitannins. In: Chemistry and biology of ellagitannins: an underestimated class of bioactive plant polyphenols. Ed. S. Quideau. World Scientific Singapore 293-297.

Tomas-Barberan F.A., Seeram N.P., Espin J.C., 2006. Bioavailability of pomegranate polyphenols. In: Ancient roots to modern medicine. Eds N.P. Seeram, R.N. Schulman, D. Heber. CRC Boca Raton, USA, 3, 45-60.

Törrönen R., 2009. Sources and health Effects of dietary ellagitannins. In: Chemistry and biology of ellagitannins: an underestimated class of bioactive plant polyphenols. Ed. S. Quideau. World Scientific Singapore, 298-319. 
Umar A., Boisseau M., Segur M.C., Begaud B., Moore N., 2003. Effect of age of Armagnac extract and duration of treatment on antithrombotic effects in a rat thrombosis model. Thromb. Res. 111, 3, 185-189.

Villarreal-Lozoya J.E., Lombardini L., Cisneros-Zevallos L., 2007. Phytochemical constituents and antioxidant capacity of different pecan Carya illinoinensis Wangenh. K. Koch cultivars. Food Chem. 102, 4, 1241-1249.

Wang L.S., Hecht S., Carmella S., Seguin C., Rocha C., Yu N., Stoner G., 2010. Berry ellagitannins may not be sufficient for prevention of tumors in the rodent esophagus. J. Agric. Food Chem. 58, 7, 3992-3995.

Wang Y., Ma J., Chow S.C., Li C.H., Xiao Z., Feng R., Chen Y., 2014. A potential antitumor ellagitannin, davidiin, inhibited hepatocellular tumor growth by targeting EZH2. Tumour Biol. 35, 205-212.

Whitley A.C., Stoner G.D., Darby M.V., Walle T., 2003. Intestinal epithelial cell accumulation of the cancer preventive polyphenol ellagic acid - extensive binding to protein and DNA. Biochem. Pharmacol. 66, 6, 907-915.
Xiang L., Xing D., Lei F., Wang W., Xu L., Nie L., Du L., 2008. Effects of season, variety, and processing method on ellagic acid content in pomegranate leaves. Tsinghua Sci. Techn. 13, 4, 460-465.

Yamaguchi M.U., Garcia F.P., Cortez D.A.G., Ueda-Nakamura T., Dias Filho B.P., Nakamura C.V., 2011. Antifungal effects of ellagitannin isolated from leaves of Ocotea odorifera (Lauraceae). Anton. Leeuw. 99, 3, 507-514.

Yoshida T., Hatano T., Ito H., Okuda T., 2009. Structural diversity and antimicrobial activities of ellagitannins. In: Chemistry and biology of ellagitannins: an underestimated class of bioactive plant polyphenols. Ed. S. Quideau. World Scientific Singapore, 55-93.

Zafrilla P., Ferreres F., Tomás-Barberán F.A., 2001. Effect of processing and storage on the antioxidant ellagic acid derivatives and flavonoids of red raspberry (Rubus idaeus) jams. J. Agric. Food Chem. 49, 8, 3651-3655.

\title{
STRUKTURA, WYSTĘPOWANIE I AKTYWNOŚĆ BIOLOGICZNA ELAGOTANIN: PRZEGLĄD
}

\begin{abstract}
STRESZCZENIE
Tematem pracy jest struktura, występowanie oraz aktywność biologiczna elagotanin. Należą one do grupy tanin hydrolizujących, są estrami kwasu heksahydroksyfenylowego i monosacharydu. Ulegają powolnej hydrolizie w przewodzie pokarmowym, uwalniając cząsteczki kwasu elagowego. Struktura chemiczna determinuje ich właściwości fizyczne i chemiczne oraz aktywność biologiczną. Elagotaniny występują naturalnie w niektórych owocach (granaty, truskawki, jeżyny, maliny), orzechach (orzechy włoskie, migdały) oraz ziołach. Tworzą zróżnicowaną grupę bioaktywnych polifenoli o właściwościach przeciwzapalnych, antynowotworowych, antyoksydacyjnych oraz przeciwdrobnoustrojowych: antybakteryjnych, przeciwgrzybowych i antywirusowych. Elagotaniny poprawiają także kondycję naczyń krwionośnych. W artykule opisano metabolizm oraz biodostępność elagotanin i kwasu elagowego. Elagotaniny są metabolizowane w przewodzie pokarmowym przez mikrobiotę. W warunkach panujących w żołądku są stabilne i nie ulegają hydrolizie do cząsteczek wolnego kwasu elagowego ani degradacji. Absorbcja kwasu elagowego może zachodzić w żołądku. Aktywność biologiczna omawianych związków jest duża, autorzy skupili się na właściwościach przeciwdrobnoustrojowych, przeciwzapalnych i antynowotworowych. Elagotaniny wykazują aktywność przeciwdrobnoustrojową przede wszystkim w stosunku do bakterii, także antybiotyko-opornych szczepów takich, jak metycylinooporny Staphylococcus aureus oraz wobec niektórych grzybów i wirusów.
\end{abstract}

Słowa kluczowe: elagotaniny, taniny hydrolizujące, aktywność biologiczna

For citation - Do cytowania

Lipińska L., Klewicka E., Sójka M., 2014. Structure, occurrence and biological activity of ellagitannins: a general review. Acta Sci. Pol., Technol. Aliment. 13(3), 289-299. 